\title{
Response to chitin in suspension-cultured Citrus aurantium cells
}

\author{
Maria I. Gallão ${ }^{1 *}$, Angelo L. Cortelazzo², Manoel P. S. Fevereiro ${ }^{3}$ and Edy S. de Brito ${ }^{4}$ \\ ${ }^{1}$ Departamento de Biologia, Universidade Federal do Ceará, 60.455-760 Fortaleza, CE, Brasil. ${ }^{2}$ Universidade Estadual \\ de Campinas, 13.083-970 Campinas, SP, Brasil. ${ }^{3}$ Dept. Cell Biology, ITQB-UNL, Oeiras, Portugal. ${ }^{4}$ Embrapa \\ Agroindústria Tropical, 60.455-760 Fortaleza, CE, Brasil.*Corresponding author: edybel@ufc.br
}

Received: 27 February 2007; Returned for revision: 10 April 2007; Accepted: 27 June 2007

Morphological changes and enzyme activity in suspension-cultured cells of Citrus aurantium were followed after chitin elicitation. Chitin oligomers presented a rapid effect with a maximum activity after $3 \mathrm{~h}$ followed by a gradual decrease to the original levels at $8 \mathrm{~h}$ of incubation. Cell walls presented a lignification process and the cytoplasmatic protein became less reactive to anionic stains. In the treated material a reduction in starch grain size, an increase in the number of autophagic vacuoles, deposition of secretion in the pericellular space and a defibrillation of the cell-wall polymers were observed. Chitin oligomers increased peroxidase and L-phenylalanine ammonia-lyase activities. Extracellular peroxidase activity increased from $0.20 \mathrm{U} \mathrm{mL}^{-1}$ after $1 \mathrm{~h}$ to $0.45 \mathrm{U} \mathrm{mL}^{-1}$ at $3 \mathrm{~h}$ followed by a gradual decrease up to $8 \mathrm{~h}$. The peroxidase isoenzyme pattern revealed a predominance of basic isoenzymes in these cells.

Key words: chitin, Citrus aurantium, elicitation, L-phenylalanine ammonia-lyase, peroxidase

Respostas a quitina em cultura de células de Citrus aurantium em suspensão: As mudanças morfológicas e atividade enzimática em cultura de células de Citrus aurantium em suspensão foram acompanhadas após eliciação com quitina. Os oligômeros de quitina apresentaram um rápido efeito, com uma atividade máxima após 3 h, seguida de um decréscimo gradual aos níveis originais com $8 \mathrm{~h}$ de incubação. As paredes celulares apresentaram processo de lignificação e as proteínas citoplasmáticas tornaram-se menos reativas aos corantes aniônicos. Nos materiais tratados observou-se uma redução no tamanho dos grãos de amido, um aumento no número de vacuólos autofágicos, deposição de secreção no espaço pericelular e desfibrilação dos polímeros da parede celular. Os oligômeros de quitina induziram a atividade da peroxidase e da L-fenilalanina amônia-liase. A atividade das peroxidases extracelulares aumentou de $0.20 \mathrm{U} \mathrm{mL}^{-1}$ após 1 $\mathrm{h}$ para $0.45 \mathrm{U} \mathrm{mL}^{-1} \mathrm{em} 3 \mathrm{~h}$, seguida de um decréscimo gradual até $8 \mathrm{~h}$. O padrão de isoenzimas revelou uma predominância de isoenzimas básicas.

Palavras-chave: Citrus aurantium, eliciação, L-fenilalanina amônia-liase, peroxidase quitina

\section{INTRODUCTION}

Stress can produce cell wall changes in plants observed by biochemical and morphological techniques (McGhie et al., 1997). Lignification appears to be the major defense strategy in many systems (Nicholson and Hammerschimdt, 1992) and several studies on plant/ pathogen interactions have shown that even walls of young tissues can substantially lignify if the cells are challenged by wounding or attack of parasitic fungi
(Walter, 1992; Dixon et al., 2002).

Chitin is an important component in shells of arthropods and cell walls of some fungi and is widely used as an eliciting agent of cell defense reactions in plants (Negrel and Javelle, 1995; Stacey and Shibuya, 1997; Shibuya and Minami, 2001). When fragmented, chitin ( $\beta-1,4-N$-acetylglucosamine oligomers) can elicit these defenses, including phytoalexin production (Yamada et al., 1993; Ramonell et al., 2005), localized deposition of lignin and an increase in peroxidase (EC 
1.11.1.7), L-phenylalanine ammonia-lyase (EC 4.3.1.5) and glucanase (EC 3.2.1.39) activities (Darvill et al., 1992; Boudet et al., 1995). Xyloglucan oligosaccharides (Joseleau et al., 1996; Warneck et al., 1996) and chitosan (Peltonen et al., 1997) are other saccharides used as elicitors.

Plant cell tissue culture has been used to study biosynthetic plant activity since 1902 (Verpoorte et al., 2002). Some in vitro systems permit large-scale secondary metabolite production by plant cells. Changes due to chitin hydrolysate addition sufficient to promote a detectable non-lethal morphophysiological disturbance were established for a citrus culture. This species has been used as a model for dycots in order to study the stress and its effect on enzymes related to phenolics metabolism. Accordingly, this paper describes some of the biochemical and structural changes of the cells of the model cell suspension cultures of Citrus aurantium when exposed to hydrolyzed chitin.

\section{MATERIAL AND METHODS}

Plant material: Citrus aurantium L. cells, derived from two-year-old calluses cultured into Murashige and Tucker (1969) medium containing malt extract (0.5 g L-1), were used. Cell suspensions were initiated by transferring $5 \mathrm{~g}$ of a callus to $20 \mathrm{~mL}$ of liquid medium in $125 \mathrm{~mL}$ flasks, followed by incubation at $120 \mathrm{~g}$ on an orbital shaker at $25 \pm 1^{\circ} \mathrm{C}$ in the dark. Suspensions were sub-cultured every two weeks for culture maintenance.

Elicitation assay: The hydrolyzed chitin from shells was acquired from Fine Chemical Kito (Palhoça, Santa Catarina State, Brazil), prepared as described by Villegas and Brodelius (1990) and $80 \mu \mathrm{L}$ added to the culture medium immediately following the inoculation of 2-d-old C. aurantium cultures to give a $200 \mu \mathrm{g} \mathrm{mL}-1$ final concentration. Flasks (125 mL volume) with $80 \mathrm{~mL}$ culture medium were used. Cells were collected after 1, 2, 3, 4, 6 and $8 \mathrm{~h}$ of elicitor addition. The cell suspension was filtered on a sintered glass funnel (porosity 40-90 $\mu \mathrm{m}$ ). Sterile distilled water was used for controls. Each experiment was repeated three times.

In situ analyses

Ionic material: Cells were fixed in $2 \%$ paraformaldehyde and $0.1 \%$ glutaraldehyde in $50 \mathrm{mmol} \mathrm{L}^{-1}$ phosphate buffer at $\mathrm{pH} 7$ for $4 \mathrm{~h}$ at room temperature, dehydrated in solutions of increasing ethanol concentrations, cleared in xylene for $30 \mathrm{~min}$, embedded in paraffin and sectioned at a $7 \mu \mathrm{m}$ thickness. After removal and rehydration, part of the preparations was stained with $0.1 \%$ Xylidine Ponceau (XP) in $3 \%$ acetic acid at $\mathrm{pH} 2.5$ for total cationic radicals detection. The remaining preparations were stained with $0.025 \%$ toluidine blue (TB) $\left(\lambda_{\max }=620-630 \mathrm{~nm}\right)$ in McIlvaine buffer at $\mathrm{pH} 4.0$ for anionic radicals and metachromasy $\left(\lambda_{\max }<580-590 \mathrm{~nm}\right)$ detection (Silva et al., 1997).

Polysaccharides: Part of the samples was submitted to the Periodic Acid Schiff (PAS) method, initiating with oxidation in $0.5 \%$ periodic acid for 9 min followed by Schiff's reagent for $30 \mathrm{~min}$ (Silva et al., 1997). As a control, samples of the same material were immersed in Schiff's reagent without prior oxidation. For starch grain diameter determination, 40 measurements were made.

Lignin: Phloroglucinol-HCl staining was used to detect phenolic material in the control and elicitor-treated cells. Phloroglucinol was prepared according to Vallet et al. (1996) and the stained cells were immediately detectable by a red colour observed by optical microscopy.

Transmission Electron Microscopy: The cells were fixed for $18 \mathrm{~h}$ in $2.5 \%$ glutaraldehyde, $3 \%$ sucrose and $5 \mathrm{mmol} \mathrm{L}^{-1}$ $\mathrm{CaCl}_{2}$ in $0.1 \mathrm{~mol} \mathrm{~L}^{-1}$ phosphate buffer, $\mathrm{pH} 7.2$ solution. Specimens were post-fixed with $1 \%$ osmium tetroxide in the same buffer, dehydrated in acetone and embedded in Spurr's resin (Spurr, 1969). Ultra-thin sections were stained with uranyl acetate and lead citrate and observed under the transmission electron microscope Leo 906 (Zeiss, Oberkocher, Germany) at $80 \mathrm{kV}$.

\section{Biochemical analyses}

Proteins: The protein concentration of the culture medium $\left(\mu \mathrm{g} \mathrm{L}^{-1}\right)$ and cell extracts $\left(\mathrm{mg} \mathrm{g}^{-1} \mathrm{DW}\right)$ was determined using the dye binding technique (Bradford, 1976), with BSA as a standard.

Peroxidase (POD) activity: Peroxidase activity was assayed spectrophotometrically based on the oxidation 
of guaiacol. The reaction mixture contained $5 \mathrm{mmol} \mathrm{L}^{-1}$ guaiacol and $0.5 \mathrm{mmol} \mathrm{L}^{-1}$ hydrogen peroxide in $25 \mathrm{mmol} \mathrm{L}^{-1}$ phosphate buffer ( $\mathrm{pH}$ 6.5). The activity of samples was expressed in $U \mathrm{~mL}^{-1}$, using $\varepsilon_{470 \mathrm{~nm}}=26.6$ for tetraguaiacol (Cortelazzo et al., 1996).

Phenylalanine ammonia-lyase (PAL) activity: Lyophilized material ( $0.3 \mathrm{~g})$ of cell cultures was homogenized in liquid nitrogen and then mixed with $6 \mathrm{~mL}$ of ice-cold $0.5 \mathrm{~mol} \mathrm{~L}^{-1}$ borax-borate buffer ( $\mathrm{pH} \mathrm{8.8),}$ followed by centrifugation at $17,000 \mathrm{~g}$ for $30 \mathrm{~min}$ at $4^{\circ} \mathrm{C}$. The pellet was extracted again and the resulting supernatant was filtered ( $5 \mu \mathrm{m}$ mesh) and used in the enzyme assays. The extract $(125 \mu \mathrm{L})$ was added to $1900 \mu \mathrm{L}$ of borax-borate and $600 \mu \mathrm{L}$ of a $0.1 \mathrm{~mol} \mathrm{~L}^{-1} \mathrm{~L}$ phenylalanine solution, and then incubated at $37^{\circ} \mathrm{C}$. The change in absorbance at $290 \mathrm{~nm}$ between 15 and $75 \mathrm{~min}$ was used to calculate PAL activity (Dörnenburg and Knorr, 1997).

Isoelectric focusing (IEF) of the POD from culture medium: Native isoelectric focusing was carried out in a vertical polyacrylamide minigel system $(10 \mathrm{x} 8 \mathrm{~cm}$ cell format). Ampholytes pH 3-9 (Pharmacia, Sweden) were used and electrophoresis performed using a Phast System and Phast Gel IEF 3-9 (Pharmacia, Sweden). The protein bands were detected by silver staining. Peroxidases were detected by incubating the gels in 0.1 mol L-1 acetate buffer ( $\mathrm{pH} 5.0$ ) containing $25 \mathrm{mmol} \mathrm{L}^{-1}$ guaiacol in the presence of $1 \mathrm{mmol} \mathrm{L}^{-1} \mathrm{H}_{2} \mathrm{O}_{2}$ (Melo et al., 1995).

Statistical analysis: Enzyme activity data was evaluated by ANOVA and means compared by Tukey's test using the software Statistica 5.0.

\section{RESULTS}

The results of stained material from the several methods employed are shown in Table 1. The cytoplasmic protein colour intensity of $C$. aurantium cells decreases after $1 \mathrm{~h}$ of elicitation and returned gradually to the initial intensity at $6 \mathrm{~h}$. The control group showed highly metachromatic cell walls. When chitin was added to the culture the metachromasy was reduced up to $3 \mathrm{~h}$, followed by a recovery of this colouration at the end of the incubation time. The elicited cells stained red with phloroglucinol/ $\mathrm{HCl}$, with a high intensity after $3 \mathrm{~h}$ of treatment while no stain was observed in the controls (Figure $1 \mathrm{~A}-\mathrm{B})$. After $3 \mathrm{~h}$ a reduction in intensity of the phloroglucinol reaction was found (Table 1).

The PAS method stained cell walls and starch (Figure 1C-D). The starch grains were smaller and more numerous in the treated material (Figure 1D). The diameter of these grains was $3.5 \pm 0.8 \mu \mathrm{m}$ in control cells and $2.4 \pm 0.5 \mu \mathrm{m}$ in $3 \mathrm{~h}$ elicited cells. Cell wall polysaccharides stained by PAS did not present detectable changes during the culture time.

The ultrastructure of the elicited cells apparently remained unchanged (Figure 1E-F). However, differences in the nuclei were observed, with more compacted chromatin, presence of evident nucleoli, and an electrondense nuclear envelope at $2 \mathrm{~h}$ (Figure 1E) as compared to $6 \mathrm{~h}$ of treatment application (Figure $1 \mathrm{~F}$ ). The vacuole number changed with the treatment and became more numerous and smaller after 2-5 h (Figure 1E-F), with the appearance of autophagic vacuoles (Figure 2C-D). The deposition of dense material at the pericellular space could also be observed (Figure 2E).

In control cells, damaged cell walls with a fibrillar aspect were not observed (Figures 2A and 2F), but presented increasing and irreversible disintegration of their polysaccharides in response to the chitin (Figure $2 \mathrm{G}-\mathrm{J})$. This phenomenon consisted in the partial release of a narrow fringe of microfibrils that became oriented perpendicularly to the surface of the cell wall (Figure $2 G$ ). Associated with the surface modifications, changed reactivity to uranyl acetate staining was visible (Figure $2 \mathrm{G}$ and $2 \mathrm{~J})$.

Chitin hydrolysate statistically $(P<0.05)$ enhanced the activity of extracellular POD in cell suspension cultures of $C$. aurantium, with an increase up to $3 \mathrm{~h}$ followed by a decrease returning to the initial value (Table 2). A statistically significant difference was also observed in the control experiment, but it was less intense than in the chitin experiment.

Similarly to POD, PAL activity also increased over the first $3 \mathrm{~h}$. This increase, from $0.020 \mathrm{U} \mathrm{g}^{-1}$ at $1 \mathrm{~h}$ to $0.028 \mathrm{U}$ $\mathrm{g}^{-1}$ at $3 \mathrm{~h}$, was followed by a decrease to $0.002 \mathrm{U} \mathrm{g}^{-1}$ at $4 \mathrm{~h}$. Activity of PAL also increased in the control experiments, from $0.009 \mathrm{U} \mathrm{g}^{-1}$ at $1 \mathrm{~h}$ to $0.019 \mathrm{U} \mathrm{g}^{-1}$ at $3 \mathrm{~h}$. Thereafter, the 
Table 1. Structures stained in Citrus aurantium cells eliceted by a chitin hydrolizate. $\mathrm{TB}=$ Toluidine Blue, PAS $=$ Periodic Acid Schiff, and XP = Xylidine Ponceau. $-=$ no stain, $+=$ fairly stained, $++=$ stained, and $+++=$ strongly stained .

\begin{tabular}{|c|c|c|c|c|c|c|c|}
\hline \multirow{2}{*}{ Structure } & \multirow{2}{*}{ Control } & \multicolumn{6}{|c|}{ Chitin eliceted } \\
\hline & & $1 \mathrm{~h}$ & $2 \mathrm{~h}$ & $3 \mathrm{~h}$ & $4 \mathrm{~h}$ & $6 \mathrm{~h}$ & $8 \mathrm{~h}$ \\
\hline \multicolumn{8}{|l|}{ Cell wall } \\
\hline Acidic sugars (TB) & $+++^{\mathrm{b}}$ & $+1+$ & $H$ & + & $H$ & $H+$ & $H+$ \\
\hline Neutral sugars (PAS) & $+1+$ & $+1+$ & $+1+$ & $H+$ & $+1+$ & $+1+$ & $+H$ \\
\hline Metacromasy (TB) & $+1+$ & $H$ & + & - & + & + & $+H$ \\
\hline Lignin (Phloroglucinol) & - & + & $H$ & $H+$ & + & + & - \\
\hline \multicolumn{8}{|l|}{ Cytoplasm } \\
\hline Protein (XP) & $H$ & + & + & + & + & + & $H$ \\
\hline Starch grain (PAS) & $+1+$ & $+1+$ & $+1+$ & $+1+$ & $+1+$ & $+1+$ & $+1+$ \\
\hline
\end{tabular}

Table 2. Activities of peroxidases (POD, $\mathrm{U} \mathrm{L}^{-1}$ medium) and phenylalanine ammonia-lyase (PAL, $\mathrm{U} \mathrm{kg}^{-1}$ cells) of control and chitin-treated Citrus aurantium cells. Values are the mean $\pm \mathrm{SD} ; n=3$. Within a line, means with different letters are significantly different (Tukey's test, $P \leq 0.05$ ). Within each time, means for chitin-treated cells marked with an asterisk differ from the controls ( $t$ test, $P \leq 0.05)$.

\begin{tabular}{|c|c|c|c|c|c|c|c|}
\hline \multirow{2}{*}{ Enzyme } & \multirow{2}{*}{ Treatment } & \multicolumn{6}{|c|}{ Time (h) } \\
\hline & & 1 & 2 & 3 & 4 & 6 & 8 \\
\hline \multirow[t]{2}{*}{$\overline{\mathrm{POD}}$} & Control & $55 \pm 20^{b}$ & $123 \pm 30^{\mathrm{a}}$ & $80 \pm 30^{\mathrm{ab}}$ & $103 \pm 20^{\mathrm{ab}}$ & $63 \pm 10^{b}$ & $88 \pm 20^{\mathrm{ab}}$ \\
\hline & Chitin & $175 \pm 80^{\mathrm{b}}$ & $393 \pm 30^{\mathrm{a} *}$ & $437 \pm 70^{a *}$ & $80 \pm 10^{\mathrm{bc}}$ & $48 \pm 10^{\mathrm{bc}}$ & $30 \pm 40^{c}$ \\
\hline \multirow[t]{2}{*}{ PAL } & Control & $9 \pm 1^{\mathrm{c}}$ & $14 \pm 1^{\mathrm{b}}$ & $19 \pm 1^{\mathrm{a}}$ & $4 \pm 1^{d}$ & $1 \pm 1^{\mathrm{e}}$ & $1 \pm 1^{\mathrm{e}}$ \\
\hline & Chitin & $20 \pm 1^{\mathrm{c} *}$ & $26 \pm 1^{\mathrm{b} *}$ & $28 \pm 1^{\mathrm{a} *}$ & $2 \pm 1^{\mathrm{d}}$ & $1 \pm 1^{\mathrm{e}}$ & $1 \pm 1^{\mathrm{e}}$ \\
\hline
\end{tabular}

activity decreased reaching a final value similar to that of the chitin-treatment sample (Table 2).

The $C$. aurantium POD isoenzyme patterns showed the presence of basic isoenzymes in the control and chitin-treated cultures. Elicited cultures showed an increased intensity in bands with pI 8.45 and 8.65 after 1 $3 \mathrm{~h}$ of stimulation with chitin (Figure $3 \mathrm{~A}$ ). Isoenzymes with pI 6.85, 7.35, 8.15 and 9.30 (Figure 3A) were also present. After $4 \mathrm{~h}$, only isoenzymes with pI $8.15,8.45$ and 9.30 were detected. From $1 \mathrm{~h}$ to $4 \mathrm{~h}$ the bands were intense in the chitin-treated material whereas at $6 \mathrm{~h}$ and $8 \mathrm{~h}$ the control bands had a higher intensity (Figure 3B).

\section{DISCUSSION}

The elicitation time of chitin oligosaccharides varies greatly among plant species, being 6 to $10 \mathrm{~h}$ in Oryza sativa (Ren and West, 1992) and $40 \mathrm{~h}$ for Vanilla planifolia (Funk and Brodelius, 1990). In our work with $C$. aurantium cells the greatest changes occurred after $3 \mathrm{~h}$ of elicitation.
Colour change after TB staining indicates a strong reduction in anionic radicals present in pectic substances (Silva et al., 1997) and/or a lignin deposition as a response to the stress induced by chitin. The difference was due to stain planar molecule accumulation in the first case (violet colour), in contrast to the great distance of the negative radicals in the lignified material, with an increased distance of the stain molecules (green colour). The detection of coniferyl aldehyde, emphasized by the red colour after the phloroglucinol reaction support the hypothesis of deposition of phenolic compounds in the cell walls of cells treated with chitin (Vallet et al., 1996).

Small vesicles in the extracellular space were reported by Fransz and Schell (1991), who suggested that this was related to nutrient flow. Autophagic vacuoles present in the cytoplasm of $C$. aurantium cells could be related to an increase in metabolic activities as reported in other species (Piqueras et al., 1994). This degradation process can reinforce the hypothesis that there was an energy increase due to the metabolic activity of the stressrelated molecules and finds support in the alteration in 

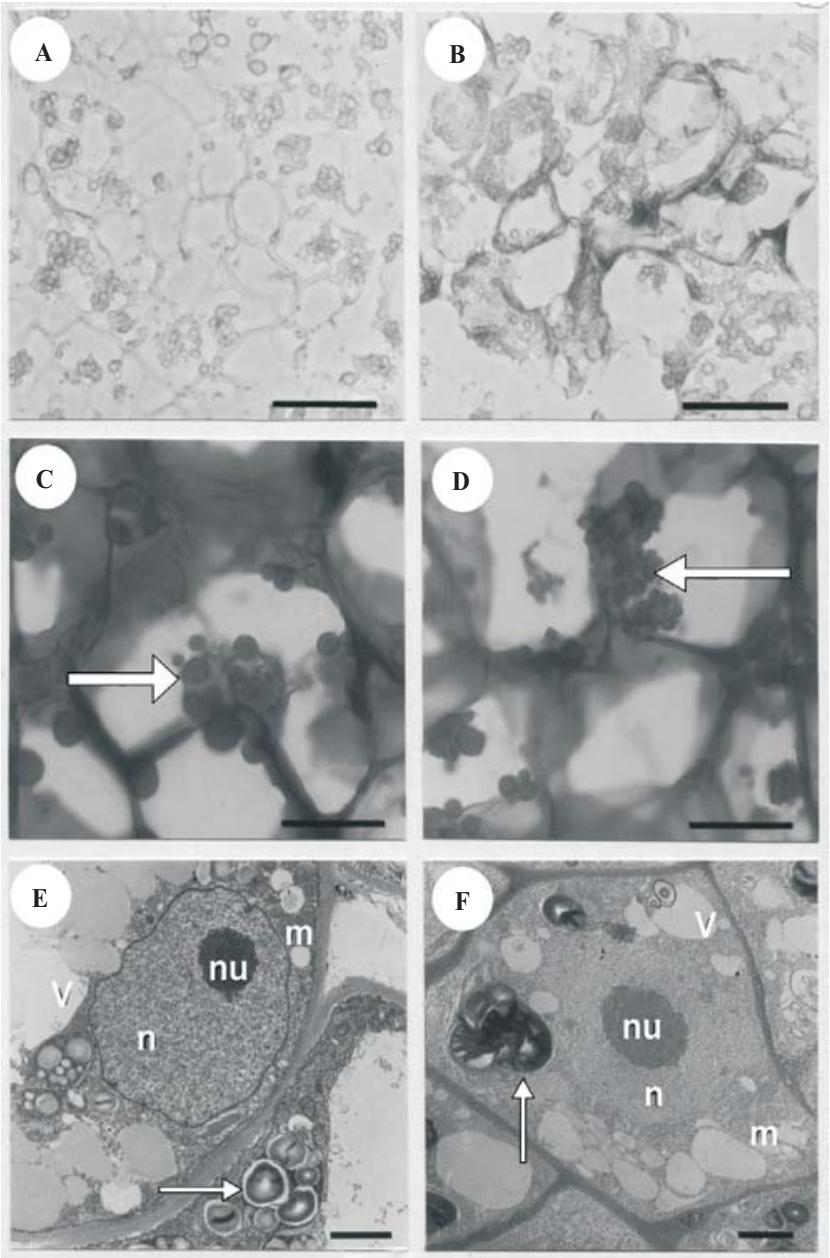

Figure 1. Citrus aurantium cells. Phloroglucinol/HCL, control and 3-h elicited cells, respectively $(\mathbf{A}, \mathbf{B})$. Periodic acid Shiff method - this method stains stained cell walls and starch $(\rightarrow)$; control and 3-h elicited cells, respectively (C,D). Ultra-structure after chitin elicitation; 2-h elicited showing more compacted chromatin and electrondense nuclear envelope (E); and 6-h elicited (F) showing nuclei (n) and looser nucleoli, numerous vacuoles (v), mitochondria $(\mathrm{m})$ and starch $(\rightarrow)$ in the cytoplasm of the cells. bar: (A,B) $47 \mu \mathrm{m} ;(\mathbf{C}, \mathbf{D}) 14 \mu \mathrm{m} ;(\mathbf{E}, \mathbf{F}) 4 \mu \mathrm{m}$.

number and size of the starch grains. In C. limon calli submitted to salt stress (Piqueras et al., 1994) an increase in lipidic bodies number was observed as an energy reserve to be used by the cell to compensate the stress.

The disintegration of the polysaccharides of cell walls from orange cells in response to chitin hydrolysate was similar to that observed in the cells submitted to other biologically active oligosaccharides (Joseleau et al., 1996). This can be a consequence of the loosening of the
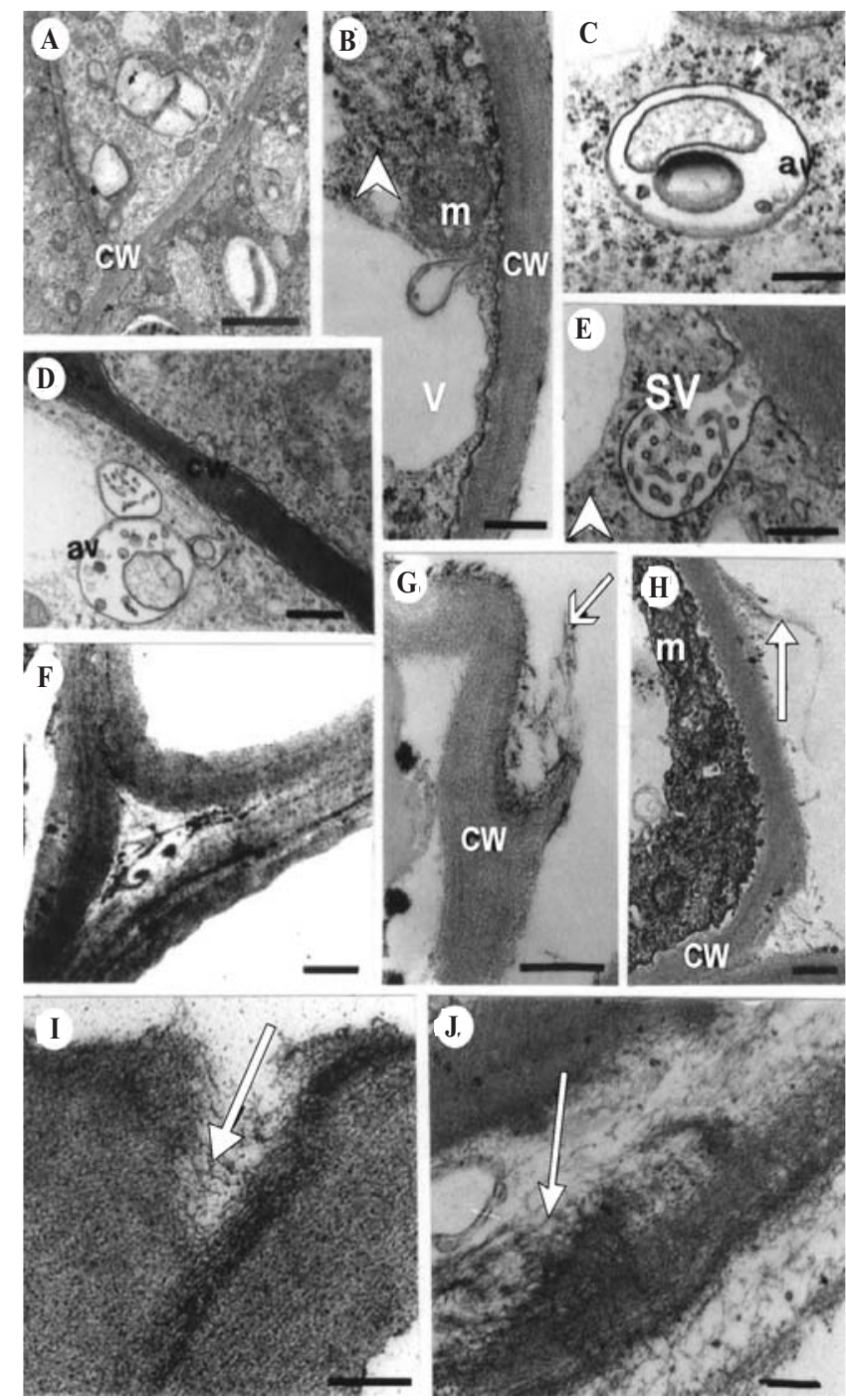

Figure 2. Ultra-structure of Citrus aurantium cell suspensions. Cell wall (cw), mitochondria (m), vacuoles $(\mathbf{v})$, ribosomes $(\boldsymbol{\nabla})$ and control material $(\mathbf{A}, \mathbf{F})$ showing fibrillar aspect of the cell walls. 2-h elicited cell (B). 6-h elicited cell (C,D) showing autophagic vacuoles (av). 8helicited material $(\mathbf{E})$ showing secretion vesicle (Sv). Elicited material $(\mathbf{G}, \mathbf{J})$ showing crescent defibrillation of the cell wall polymers $(\rightarrow)$. 2-h elicited $(\mathbf{G}, \mathbf{H}), 3$-h elicited $(\mathbf{I})$ and 8 h elicited (J). bar: (A) $2 \mu \mathrm{m} ;(\mathbf{B}, \mathbf{C}, \mathbf{E}, \mathbf{G}, \mathbf{I}, \mathbf{J}) 0.3 \mu \mathrm{m} ;(\mathbf{D}, \mathbf{F}, \mathbf{H}) 0.5$ $\mu \mathrm{m}$.

cell wall, due to rupture of covalent interactions between the cell wall polymer chains by the activated hydrolytic enzymes associated with the cell wall. As a consequence of that enzymatic action, no cellulosic polymers were ruptured (McDougall and Fry, 1991), giving rise to a fibrillar network, which finally breaks into fibrillar 

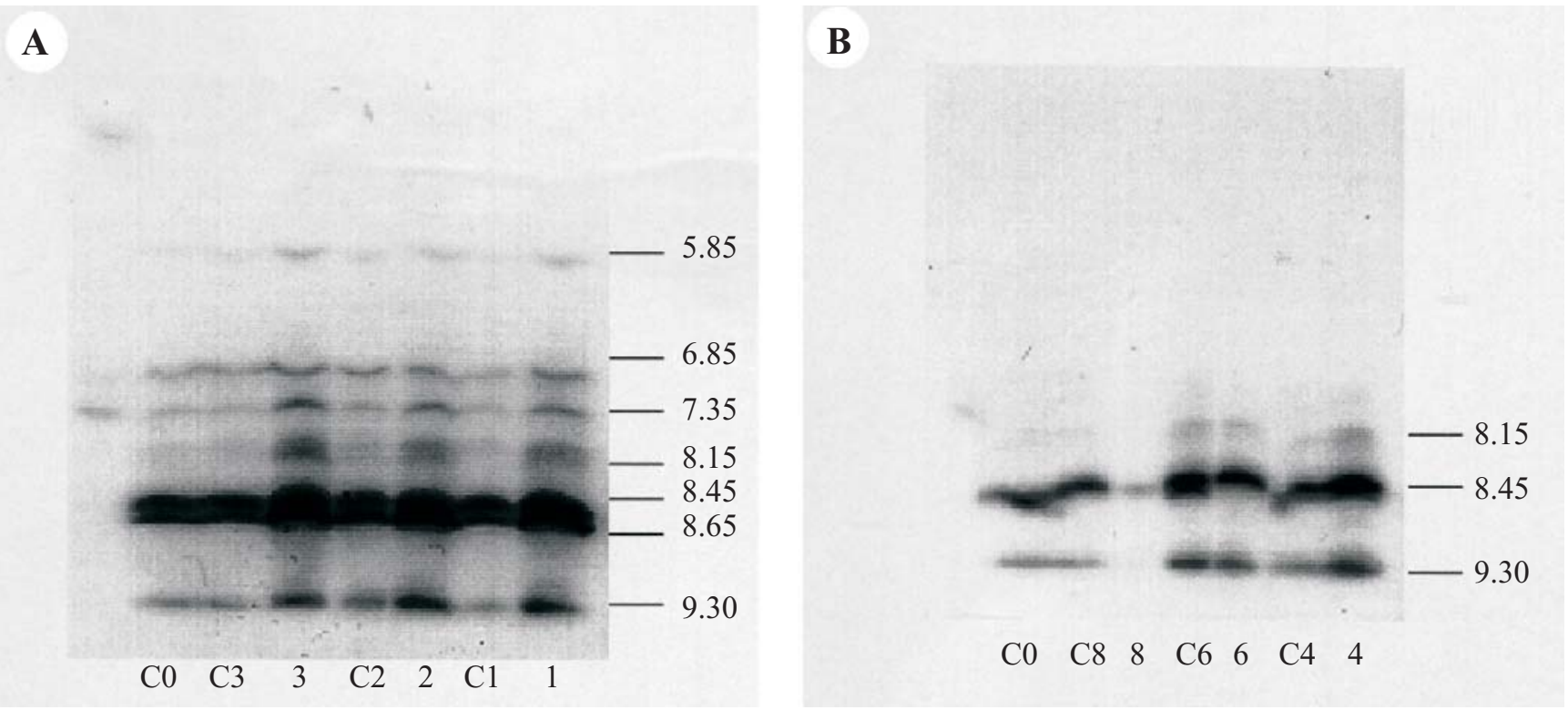

Figure 3. Effects of chitin on the activity of extracellular peroxidase isoforms in suspension-cultured Citrus aurantium cells after 1,2, $3 \mathrm{~h}$ of chitin treatment, and control (C) cells at the same time (A); and after 4, 6, $8 \mathrm{~h}$ of chitin treatment and control (C) cells at the same time $(\mathbf{B})$.

elements. This can be reinforced by the fact that the material was more reactive to the uranyl acetate and lead citrate, indicating an acid composition, which would explain the stronger affinity for the metal.

Peroxidases catalyze the cross-linking of pre-formed cell wall phenols and are involved in lignin polymerization (Messner and Boll, 1994). These enzymes play an important role in the defence against pathogens, with an increase in their activity being related to mechanical stress or to exposure to a fungal elicitor (Campbell and Ellis, 1992; Wakamatsu and Takahama, 1993; Whetten et al., 1998). The increase in the POD activity of $C$. aurantium cells treated with chitin fragments indicates that these fragments are capable of inducing a stress response in these cells. As many authors have observed, chitin has the capacity to elicit suspension cultured cells from species such as slash pine (Lesney, 1990), potato (Dörnenburg and Knorr, 1997) and wheat (Vander et al., 1998).

Elicited and non-elicited cultures expressed basic isoenzymes but the elicited material presented a greater activity. Many attempts have been made to define the functions of anionic or cationic peroxidase isoenzymes. Anionic isoenzymes have been suggested to be involved in the cross-linking of cell-wall polymers and in lignification (Gaspar et al., 1985), although cationic peroxidases have also been implicated in the latter process (Zheng and Van Huystee, 1991; Van Huystee and Zheng, 1993). Our results show that the basic peroxidase isoenzymes participate in the response of $C$. aurantium to stress.

Phenylalanine ammonia-lyase catalyses the first step of the biosynthesis of defence-related phenylpropanoids by synthesizing antimicrobial metabolites (e.g. phytoalexins and lignin). In cultured cells of $C$. aurantium, an increase in this enzyme activity is connected to the phloroglucinol reaction in which the higher deposition of red precipitate occurred after $3 \mathrm{~h}$. Increased PAL activity in response to biotic and abiotic factors has been reported in many species, e.g., potato suspension cultures (Dörnenburg and Knorr, 1997), hop cell suspension cultures (Trevisan et al., 1997) and Hypericum perforatum cell suspension culture (Gadzovska et al., 2007).

The increased PAL and peroxidase activities observed in $C$. aurantium cells in the first hours showed that these cells quickly respond to the chitin elicitor. The subsequent decrease to lower values for both enzyme activities indicates the capacity of this culture to produce non-lignified cells and, consequently, to restore their nor- 
mal metabolism.

Chitin induced a fast $(2 \mathrm{~h})$ defence response in $C$. aurantium suspension cells. After $6 \mathrm{~h}$ the culture was able to restore their normal development. An increase in basic peroxidases and PAL activity was observed that was associated with lignification. Morphological changes were similar to cell aging demonstrating the capacity of the chitin to induce cell aging and death for this dicot.

Acknowledgment We wish to thank Capes/PICDT-Brazil for supporting M.I. Gallão.

\section{REFERENCES}

Boudet AM, Lapierre C, Grima-Pettenati J (1995) Biochemistry and molecular biology of lignification. New Phytol. 129:203-236.

Bradford MM (1976) A rapid and sensitive method for the quantitation of microgram quantities of protein utilizing the principle of protein-dye binding. Anal. Biochem. 72:248-254.

Campbell MM, Ellis BE (1992) Fungal elicitor-mediated responses in pine cell cultures: I. Induction of phenylpropanoid metabolism. Phytochemistry 31:737742.

Cortelazzo AL, Marais MF, Joseleau JP (1996) Changes in peroxidases in the suspension culture of Rubus fruticosus during growth. Plant Cell Tissue Organ Cult. 46:27-33.

Darvill AG, Augur C, Bergmann C, Carlson RW, Cheong JJ (1992) Oligosaccharins-oligosaccharides that regulate growth, development and defense responses in plants. Glycobiology 2:181-198.

Dixon RA, Achnine L, Kota P, Liu C, Redy MSS, Wang L (2002) The phenylpropanoid pathway and plant defence - a genomics perspective. Mol. Plant Pathol. 3:371-390.

Dörnenburg H, Knorr D (1997) Evaluation of elicitor- and high-pressure-induced enzymatic browning utilizing potato (Solanum tuberosum) suspension cultures as a model system for plant tissues. J. Agric. Food Chem. 45:4173-4177.

Fransz PF, Schell JHN (1991) An ultrastructural study on the early development of Zea mays somatic embryos. Can. J. Bot. 69:858-865.

Funk C, Brodelius P (1990) Influence of growth regulators and elicitor on phenylpropanoid metabolism in suspension cultures of Vanilla planifolia. Phytochemistry 29:845-848.
Gadzovska S, Maury S, Delaunay A, Spasenoski M, Joseph C, Hagége D (2007) Jasmonic acid elicitation of Hypericum perforatum L. of phenylpropanoids and naphtodianthrones. Plant Cell Tissue Organ Cult. 89:113.

Gaspar T, Penel C, Castillo FJ, Greppin H (1985) A two step control of basic and acidic peroxidases and its significance for growth and development. Physiol. Plant. 64:77-83.

Joseleau JP, Cortelazzo AL, Chambat G, Ruel K (1996) Activation of peroxidases from plant cell suspensions by xyloglucan oligosaccharide elicitors. Plant Peroxid. Newslett. 8:8-13.

Lesney MS (1990) Effect of 'elicitors' on extracellular peroxidase activity in suspension-cultured slash pine (Pinus elliottii Engelm.). Plant Cell Tissue Organ Cult. 20:173-175.

McDougall GJ, Fry SC (1991) Xyloglucan nonasaccaride, a naturally occurring oligosaccharin, arises in vitro by polysaccharide breakdown. J. Plant Physiol. 137:332336.

McGhie TK, Masel NP, Maclean D, Croft BJ, Smith GR (1997) Biochemical responses of suspension-cultured Sugarcane cells to an elicitor derived from the root pathogen Pachymetra chaunorhiza. Aust. J. Plant Physiol. 24:143-149.

Melo NS, Cabral JMS, Fevereiro MP (1995) Extracellular peroxidases from cell suspension cultures of Vaccinium myrtillus. Purification and characterization of two cationic enzymes. Plant Sci. 106:177-184.

Messner B, Boll M (1994) Extracellular peroxidases of suspension culture cells of spruce (Picea abies): fungal elicitor-induced inactivation. Plant Cell Tissue Organ Cult. 36:81-90.

Murashige T, Tucker DPH (1969) Growth factor requirements of Citrus tissue culture. In: Chapman HD (ed), Proceedings of the First International Citrus Symposium, pp.1155-1161. University of California, Riverside.

Negrel J, Javelle F (1995) Induction of phenylpropanoid and tyramine metabolism in pectinase- or pronaseelicited cell suspension cultures of tobacco (Nicotiana tabacum). Physiol. Plant. 95:569-574.

Nicholson RL, Hammerschmidt R (1992) Phenolic compounds and their role in disease resistance. Annu. Rev. Phytopathol. 30:369-389.

Peltonen S, Mannoen L, Karjalainen R (1997) Elicitorinduced changes of phenylalanine ammonia-lyase activity in barley cell suspension cultures. Plant Cell Tissue Organ Cult. 50:185-193. 
Piqueras A, Olmos E, Hellín E (1994) Cytological changes related with salt tolerance in embriogenic callus of Citrus limon. Plant Cell Tissue Organ Cult. 39:13-18.

Ren Y, West CA (1992) Elicitation of diterpene biosynthesis in rice (Oryza sativa L.) by chitin. Plant Physiol. 99:1169-1178.

Ramonell K, Berrocal-Lobo M, Koh S, Jinrong W, Edwards H, Stacey G, Somerville S (2005) Loss-of-function mutations in chitin responsive genes show increased susceptibility to the powdery mildew pathogen Erysiphe cichoracearum Plant Physiol. 138:1027-1036.

Shibuya N, Minami E (2001) Oligosaccharide signalling for defense resposnses in plants. Physiol. Mol. Plant Pathol. 59:223-233.

Silva TRG, Cortelazzo AL, Dietrich SMC (1997) Cytological aspects of storage mobilization in seeds of Dalbergia miscolobium during germination and plantlet growth. Ciên. Cult. 49:219-222.

Spurr AR (1969) A low viscosity epoxy resin embedding medium for electron microscopy. J. Ultrastruct. Res. 26:31-43.

Stacey G, Shibuya N (1997) Chitin recognition in rice and legumes. Plant Soil 194:161-169.

Trevisan MTS, Scheffer JJC, Verpoorte R (1997) Effect of elicitation on the peroxidase activity in some cell suspension cultures of hop, Humulus lupulus. Plant Cell Tissue Organ Cult. 48:121-126.

Vallet C, Chabbert B, Czaninski Y, Monties B (1996) Histochemistry of lignin deposition during sclerenchyma differentiation in alfalfa stems. Ann. Bot. 78:625-632.

Van Huystee RB, Zheng X (1993) Cationic peanut peroxidase and the oxidation of ferulic acid. Phytochemistry 34:933-999.
Vander P, Varum KM, Domard A, Gueddari NEE, Moerschbacher BM (1998) Comparison of the ability of partially N-acetylated chitosans and chitooligosaccharides to elicit resistance reactions in wheat leaves. Plant Physiol. 118:1353-1359.

Verpoorte R, Contin A, Memelink J (2002) Biotechnology for the production of plant secondary metabolites. Phytochem. Rev. 1:13-25.

Villegas M, Brodelius PE (1990) Elicitor-induced hydroxycinnamoyl-CoA: tyramine hydroxycinnamoyltransferase in plant cell suspension cultures. Physiol. Plant. 78:414-420.

Wakamatsu K, Takahama U (1993) Changes in peroxidase activity and in peroxidase isozymes in carrot callus. Physiol. Plant. 88:167-171.

Walter MH (1992) Regulation of lignification in defense. In: Meins BT (ed), Genes Involved in Plant Defense, pp.327-352. Springer, Wien.

Warneck HM, Haug T, Seitz HU (1996) Activation of cell wall-associated peroxidase isoenzymes in pea epicotyls by a xyloglucan-derived nonasaccharide. J. Exp. Bot. 47:1897-1904.

Whetten RW, MacKay JJ, Sederoff RR (1998) Recent advances in understanding lignin biosynthesis. Annu. Rev. Plant Physiol. Plant Mol. Biol. 49:585-609.

Yamada A, Shibuya N, Kodama O, Akatsuka T (1993) Induction of phytoalexin formation in suspensioncultured rice cells by $\mathrm{N}$-acetylchitooligosaccharides. Bios. Biotechnol. Biochem. 57:405-409.

Zheng X, Van Huystee RB (1991) Oxidation of tyrosine by peroxidase isozymes derived from peanut suspension culture medium and by isolated cell walls. Plant Cell Tissue Organ Cult. 25:35-43. 